\title{
The Role of Apostolic Faith Mission in Zimbabwe in the Fight Against Coronavirus
}

\author{
Never Pavari \\ College of Peace, Leadership, and governance, Africa University, Zimbabwe \\ E-mail: pastorpavari@yahoo.co.uk
}

Received: Jun. 14, 2020 Accepted: Aug. 26, 2020 Online published: Sep. 13, 2020

doi:10.5296/jpag.v10i3.17690～URL: https://doi.org/10.5296/jpag.v10i3.17690

\begin{abstract}
Practical theology, according to Stone (2002) posits that churches should care and sacrifice for the community. Consequently, Christianity has been handling epidemics for more than 2000 years. This paper seeks to assess the role that is being played by the leadership in Apostolic Faith Mission in Zimbabwe (AFMZ) in response to the COVID-19 pandemic. The term leadership in this paper refers to those in charge of the congregants and this includes church pastors, reverends, bishops and elders. Church leaders are people who play influential roles within their faith communities and the broader local community. They benefit from trust and exercise moral authority over members of their local faith community, and shape public opinion in the broader community and even at the national or international level. The paper argues that the church and its leadership play an important role in providing moral guidance to tackle COVID-19 and also to dispel fear that stalks communities alongside the disease. In order to evaluate the role that AFMZ leadership is playing in the fight against COVID-19, the paper employs a qualitative research approach in its exploration and analysis of data gathered through an online survey method. The paper found out that the church is playing a vital role in communities by communicating messages of hope in the midst of severe fears of COVID-19. It also found out that the church leadership is playing a vital role in changing people's attitudes toward COVID-19 by providing in depth discussions of safety measures in times of the pandemic. Lastly, the paper found out that the church leadership is not doing enough on the practical matters like providing food to the most vulnerable groups in their respective communities and for quarantined patients, maintaining clear communication with families and ensuring that basic primary care is not undermined due to limited finances. The paper therefore recommends that more finance should be availed to church leadership especially from the main church coffers to enable them to meet the above-mentioned demands.
\end{abstract}

Keywords: practical theology, AFMZ, leadership, response, COVID-19, Zimbabwe 


\section{Introduction: Context and Technical Background of Coronavirus Disease (COVID-19)}

According to the Centre for Disease Control (CDC), coronavirus disease also known as COVID-19, actually began in Wuhan, China as a result of an animal-to-person spread from a market. The virus has spread to many locations internationally. In the United States of America for example, COVID-19 cases have been confirmed in New York, California, Oregon and Washington State. Deaths have been reported in both Washington State and California. In some other countries including the United States of America, the tragic news has forced leaders to declare a State of Emergency to order its citizens to stay indoor as the search for a permanent cure have been carried out by World Health Organisations.

The Zimbabwean government declared the COVID-19 crisis a 'national disaster' on Friday, March 27, a move allowing it to commandeer State resources towards fighting COVID-19, to use emergency regulations, and to deploy personnel for the same service. A virus that started in a minor way has actually saturated the world within a space of time. The foundation of protection of each country is now rested upon her health workers. The coronavirus that originated in Wuhan, China has killed several people and infected thousands of people. The virus has spread to 40 nations and more. These includes: France, US, UK, Malaysia, Belgium, Hong Kong, Spain, Italy, South Korea, Switzerland, Germany, Netherland, Austria, and other African countries, apart from Zimbabwe, that reported cases of the disease are Morocco, Tunisia, Egypt, Algeria, Senegal, Togo, Cameroon, Burkina Faso, the Democratic Republic of the Congo (DRC), South Africa, Nigeria, Ivory Coast, Gabon and Ghana. Most of the countries' totals are now in triple figures.

The World Health Organisation (WHO) has declared Coronavirus disease as pandemic, and to Christians and non-Christians, this is a quite challenging moment for them. They believe that the foundation of the world has been destroyed by the devil and that is why nations are in state of confusion and anxiety. While the Lord promised that certain diseases will not find their way into Christians' bodies as expressed through Exodus 23:25 which says that, "And ye shall serve the LORD your God, and he shall bless thy bread, and thy water; and I will take sickness away from the midst of thee"; one very disturbing trend in the world today is the rate at which people fall ill to Coronavirus disease. However, the Bible says that they should not harbour any fear as He (God) has given them a sound and stable mind. God has given believers the power to protection and zeal to pray for the healing from any kinds of virus, fungi, bacteria that causes infirmities in the body.

\subsection{Theological Reflection About Pandemics and the Role of Christian Leadership}

Throughout the Bible, believers are called to aid the poor, the sick, the oppressed, orphans, refugees - anyone who is vulnerable. In part, this is because all humans are made in the image of God, which confers everyone with both inherent dignity and moral responsibility. O’Mathuna (1995) says that ethical living implies acting as an authentic image of God, doing what God would do. Furthermore, the Bible portrays God in Psalm 68:5; Luke 6:20-22 and James 1:27 as the defender of the weak and helpless. This includes helping those devastated by disasters. 
For example, during the Roman Empire, the early spread of Christianity was influenced by how Christians responded to plagues. As healthy Romans fled their cities, Christians stayed and helped those in need, sometimes at the cost of their own lives (Stark, 1996). In the sixteenth century, Martin Luther commended those Christians who felt God called them to help those afflicted with the Black Death (Luther, 1527). In the nineteenth century, Henri Dunant saw first-hand the pain and suffering of wounded soldiers and committed himself to doing something about it. London (1998), says that Dunant gathered a small group of Swiss Christians, united in their theology and 'the moral sense of the importance of human life, the humane desire to lighten a little the torments' of those suffering.

Thus, disaster responders are motivated by many reasons, religious and nonreligious. Belief in God is not required to help others. The claim here is that followers of the Christian God should be motivated to help those in need. This should go beyond providing aid, as this can be a way to ease one's conscience or avoid addressing underlying injustices. Christianity calls for solidarity with others because all humans are part of one family, all equally images of God. Sobrino (2015) defined solidarity as a means of 'letting oneself be affected by the suffering of other human beings, sharing their pain and tragedy'. Jesus is the example here, as he wept over his friends' grief (John 11:35), suffered on the Cross, and knows what it is like to suffer. The God of the Bible feels with humanity, and takes on the pain of their suffering. True solidarity with those impacted by disasters should lead to internal change.

Rather than looking backwards and speculating about why God allowed a disaster, believers are called to look forward to how they can learn and grow from the event. This may be in compassion towards others, taking action to help, or learning to help better. Moreover, faith offers confidence that God can be trusted in the midst of suffering, even if much remains unclear and uncertain. This trust is based on the nature of God's character (loving, faithful, just, etc.), and not any particular outcome, no matter how desirable. Such faith includes the hope that in the future, maybe as far away as the afterlife, things will be rectified and restored to the way God intended. In this way, religious faith, for those who believe, can contribute to personal resilience in the midst of disasters.

In times of epidemics, Donnelly \& McManus (2006) revealed in an article entitled Pandemic Flu: The Role of the Church that churches and religious groups in India have been responding and are still responding to epidemics such as the HIV/AIDS by establishing care centres, raising awareness through media such as films, music and art, testing, counselling, advocacy and even the provision of respite care. Donnelly \& McManus (2006) are therefore significant in this paper in that he demonstrates some of the roles that church leadership should play in society amidst pandemics. In this regard, the church leadership apart from praying for the people, should establish healthcare centres for people infected and affected with coronavirus disease pandemic, raising awareness through their sermons on COVID-19 pandemic - how one can prevent contracting it or what to do when they get infected, counselling, advocacy and even the provision of respite care.

The Church leadership has a duty to be present and to minister in such a global healthcare emergency. Thus, the 'presence of the Church during a major incident is an important living 
out of the gospel and of following the example of Christ's ministry of being with those in need and in crisis. It also presents a sign of hope. Moreover, it provides an important testimony to the ongoing work of the Spirit through all aspects of human life, and in an eschatological sense points to the fact that even through disasters we are upheld by God (Ammerman, 2001).

That the church and its leadership have a critical role to play in the community is furthermore underpinned in the article by Mukuka \& Slonim-Nevo (2006) entitled The role of the Church in the fight against HIV/AIDS infection in Zambia. They aver that Religious organizations are key players in the care for the victims of the AIDS epidemic, but in many countries they also provide many other social services throughout the life stages, such as through provision of food, health care, work preparation, counselling programs, educational facilities, housing and elder care (Ammerman, 2001). The Church provides guidance on issues ranging from practical problems to social and political decisions. Thus, the Church is likely to influence the AIDS-related knowledge, attitudes and behaviour of youths and adults in Zambia.

According to Feldman (1995), 91 percent of adolescents understand religion to play a vital role in their lives. Infected persons do approach the Church for guidance. For instance, in Slonim-Nevo \& Mukuka ( 2005), respondents expressed their unwillingness to confide even in family members if they were infected because of shame and the fear of rejection. Counselling by the Church can therefore be much appreciated. Orubuloye et al., (1993) studied the effect of religious leaders on the behaviour of their followers and the pattern of life they choose. They found out that the Church has influenced a decline in polygamy in southern Africa and an increase in sexual restraint.

In summary, the article on The role of the church in the fight against HIV/AIDS infection in Zambia is significant in this paper in that it highlights the fact that church leadership really do play a major role in the fight of pandemics such as COVID-19 pandemic. In addition, the Church Leadership has a strong influence on the lives of its congregation. The congregation tend to listen more to the doctrine that their leadership preach. Thus, the congregation will listen more to the healthcare guidelines as prescribed by WHO and CDC on the precautionary measures to take in the COVID-19 pandemic such as the washing of hands, lockdowns, wearing of masks and sanitization when they come from leadership whom they trust so much for both spiritual and physical guidance.

On the other hand, church and its leadership are a source for support. They offer confidentiality and serves as a place of refuge. The Church provides shelter and care for both the victims and the orphaned population that have evolved as a result of the pandemics such as HIV/AIDS and coronavirus pandemic in this case. The article by Mukuka \& Slonim-Nevo (2006) is therefore significant in this paper in that it pinpoints and furthermore underscores the programs that the church leadership can embark upon in times of pandemics such as the provision of counselling services for individuals diagnosed with coronavirus disease and the establishment of special homes to take care of the sick and the orphaned victims of the coronavirus disease. Church leadership can also guide its members to be more responsive to the problem of coronavirus disease. 
It is also the role of the leadership of a church to cooperate with governmental and non-governmental organizations (NGOs) in the fight against pandemics such as COVID-19. They can respond to COVID-19 by working cooperatively with healthcare institutions, government clinics, the WHO and NGOs in the provision of protein supplements for the infected population. They can also finance their financial obligations for counselling and projects for food provision to the most vulnerable people in their respective communities through contributions from Church members. It is believed that, through its intensive efforts, the leadership of a Church has a significant impact on preventing the spread of COVID-19 in Zimbabwe.

Hodge (2000) cited various reasons for involving religious actors in humanitarian response and these include, benefiting from their experience of providing services, maximizing community impact (for example, through responsiveness to faith identities), capitalizing upon their long-term sustainable presence at the grassroots level, building on their legitimacy in the eyes of beneficiary communities, reinforcing inclusive social values and best practices and contributing to the effectiveness of programmes. Church leadership, according to Hodge (2000) help in promoting preventive health messages around the precautionary measures to take, obedience and faith. Church leadership can therefore respond to COVID-19 by identifying extracts from sacred texts that can be used to dispel myths and combat stigma (e.g. extracts which emphasise the value of every human life). Faith leaders can use these extracts to teach their congregations and to encourage family members of people displaying symptoms of coronavirus or with coronavirus to treat them with respect and kindness.

Furthermore, Hodge (2000) highlighted that church leadership play a significant role in the provision of psychological support and spiritual care in times of pandemic such as the COVID-19 pandemic. They offer spiritual support to people experiencing life-threatening illness; people receiving end-of-life care; and family members facing bereavement. They also pray for those in quarantine and in hospitals. In other words, communities rely on church leadership in times of pandemic as part of their coping mechanism (Cnaan \& Boddie, 2001) in times of disasters, enhancing communication, sharing, and compassion, and offering courage, comfort and hope.

Church leaders have the ability to leverage considerable resources in humanitarian response, including social capital, human resources, spiritual resilience, facilities, and financial support and they also have a distinctive and powerful role in bringing about behavioural and social change during times of stability and times of crisis, especially at the community level Hodge (2000). They help in the dissemination of key messages within local communities, such as through mobile communication and other local, remote means of communication, while respecting social distancing rules.

These Christian leaders can serve as peer mentors for other faith leaders who continue to contribute to the spread of the virus, by holding large gathering or giving credence to misinformation within communities. What is more, the church leadership can also help in supporting the displaced people who have lost all means of income: whether it is through cash for work, cash distribution, agriculture training or other sustainable ways of earning a 
living. The church can also help in tackling stigma. There is a risk that harmful stereotypes, stigma and pervasive misinformation related to COVID-19 could contribute to ongoing transmission, making it difficult to control coronavirus in Zimbabwe. Stigma and misinformation could also prevent potentially infected people from immediately seeking care, or lead to households hiding sick members to avoid discrimination - a particular concern for minorities and marginalised groups.

Furthermore, the church could help in slowing the pandemic through raising awareness, share correct guidance and expose misinformation, whether that be conspiracy theories about $5 \mathrm{G}$ phone masts or stories about the role of the $\mathrm{UN}$ in spreading the coronavirus disease. Church leaders have a powerful platform. They are known and trusted by their communities and when equipped with the correct knowledge are well placed to advise people. Hodge (2000) says that a key lesson from the global Ebola response was that investing in the frontline work of faith leaders and faith-based organisations saved lives. In view of the above, the leadership of AFM Zimbabwe could help in spreading well-evidenced advice on handwashing, physical distancing and when to self-isolate, where that is possible. They can also work to dispel myths, help to reduce stigma and identify social or cultural norms that may exacerbate the disease transmission, and encouraging behaviour change.

In an article by French et., (2018) the Archbishop of Canterbury says that church leaders should develop bible study packs which are a resource to help Christians reflect on their faith and scriptures in this troubling time of COVID-19. The Bible studies bring hopes and fears before God and build resilience and trust. They allow people to lament all that brings sorrow and suffering and to reflect on how they can support those most impacted by this crisis. Above all, the Bible studies seek to help the communities to find hope, in reflecting on God's presence and love, and how God shares their sorrows and sufferings and brings assurance of new life.

Churches leadership can also maintain common worship even when they cannot gather. They can uphold a shared life of prayer. They can also sustain connections to encourage those living in isolation or lockdown. And they could also continue to serve the most vulnerable and marginalised in the communities while following public health guidelines. The Archbishop furthermore says that, 'We have also learnt together from the wisdom and resilience of those parts of the community which have faced epidemics and other crises in the past [that] in the midst of the troubling headlines there is still good news of gospel and hope to be heard'.

In other words, church leadership can help in the fight against COVID-19 through providing spiritual and theological resources like prayers, bible studies, reflections; supporting community preparedness, supporting people living in lockdown: including caring for children, home schooling, coping with stress and family pressures, tackling domestic violence, sustaining hope and care for the most vulnerable and building a more connected, resilient and compassionate society for the future.

Churches have a moral duty to contribute to the nation of a social, economic, political and cultural context that facilitates the growth and fulfilment of every person. Zimbabwean 
churches, according to Kaulemu (2010) have been growing over the years. For instance, AFMZ has recently contributed foodstuffs and clothes during the cyclone IDAI which ravaged Eastern parts of Zimbabwe which saw infrastructure worth millions of dollars destroyed and people displaced and left homeless.

The literature reviewed above on the role of churches in pandemics is significant in this paper in that it managed to reveal some of the roles that church leadership have played in previous epidemics. These roles include developing, caring, equipping, informing, connecting, shepherding and discipling. However, there has not been any study that had attempted to look closely at the role that AFM Zimbabwe leadership is playing in the COVID-19 pandemic in Zimbabwe. In that respect, this paper intends to fill in that gap.

\section{Methodology}

\subsection{Brief History of Apostolic Faith Mission in Zimbabwe}

Apostolic Faith Mission (AFM), according to Togarasei (2016) is the mother of Zimbabwean Pentecostalism. It is the oldest and largest Pentecostal in Zimbabwe. The church was born on 25 May 1908 in Doornfontein by two missionaries, John G Lake and Thomas Hezmelech. In Zimbabwe, the church was founded in 1915 in Gwanda through the preaching of Manamela, a convert of the AFM of South Africa. Divine healing was the drawing card of John G Lake's ministry, which is why emphasis on healing was characteristic of AFM church services. Great emphasis was laid on the salvation of the soul, the Holy Spirit baptism, divine healing, the gifts of the Holy Spirit and living a holy life. Abstinence from intoxicating substances, eating pork, listening to and dancing unchristian music and ancestral worship were taught as signs of genuine Christianity.

The AFM uses the Presbytery system of church government and the estimated membership of the church in Zimbabwe is 2300000 (2.3 Million) comprising believers from all walks of life and of various dialects (www.afminzimbabwe,com).

\subsection{Data Collection Procedure}

In order to ascertain the role that the leadership of the Apostolic Faith Mission in Zimbabwe (AFMZ) is playing in the fight against coronavirus disease (COVID-19) in Zimbabwe the following research methods were used in gathering the data needed. Firstly, a literature review was undertaken to examine the role of Christian leadership in philanthropic responses in other countries in general and in the COVID-19 outbreak in particular. A survey monkey application - which is an online survey software that helps the researcher to create and run professional online surveys. Thus, the survey questions which were relevant to AFMZ leadership and communities were developed and sent out to 100 key AFMZ church leadership and church members via a weblink and results were viewed as respondents completed their questions.

The purpose of involving the church congregate was to validate responses from AFMZ leadership. The research was conducted over a period of one week and priority was placed on those areas that had more positive cases of coronavirus in Zimbabwe and these included 
Harare, Bulawayo and Gweru.

\section{Findings}

\subsection{Coronavirus in Zimbabwe: AFMZ Church Leadership's Response}

The COVID-19 pandemic was confirmed to have reached Zimbabwe in 20 March 2020. As of 2 June 2020 Zimbabwe, has recorded 206 confirmed cases of coronavirus, 141 active cases as of 31 May 2020, 29 have recovered as of 2 June 2020 and 4 deaths as of 2 June 2020.

Information gathered from the survey on COVID-19 pandemic reveals that 90\% of AFM church leadership who sit at different boards from National, Provincial and Assembly levels believe that COVID-19 is an infectious disease that has originated from animals. One notable response was that, 'COVID-19 is a disease transmitted through contact and it affects the lungs, and its symptoms are multiple' (Online survey dated 01/06/2020). The response above was furthermore underscored by another respondent who says that, 'covid-19 is a virus transferable from one person to the other through contact with an infected person or fluids from infected person'. According to these respondents, COVID-19 started in Wuhan in china and spread to other countries until World Health Organisation declared it a pandemic.

Other respondents described COVID-19 as something spiritual. Some of them said that it is the work of the devil while others labelled it as an act from God. One distinguished response was that, 'covid-19 is a pandemic through which God is trying to communicate a message to humanity that he is sovereign and that all humanity must turn to God for solutions' (Online survey dated 02/06/2020).

Literature reviewed above highlighted that one of the roles of church leadership is to augment government and other player's efforts in combating the further spread of pandemics. In line with that the researcher asked the leadership of AFMZ on how they responded to government and WHO directives to ensure the safety of their congregants and their responses revealed that they all complied. They stopped gathering their congregants, they encouraged them to stay indoors, and to put on facemasks when in public and to observe a one metre social distancing and if possible, to getting tested of COVID-19 if they suspect that they have the symptoms. A striking response from a respondent from Harare was that, 'we complied to government and WHO directives by ordering our congregation to stop gathering as we usually do and encouraging them not to unnecessarily travel, stay at home and maintaining good hygiene, whenever they are out, to wear masks and maintain social distancing' (Online survey dated 02/06/2020). Another respondent from Harare underscores the above when he says that, 'All precautionary guidelines were implemented as required, e.g. staying at home use of sanitisers and then for church services we used social media such as Facebook and WhatsApp and local TV station - ZBCTV' (Online survey dated 02/06/2020).

Eighty five percent $(85 \%)$ of the congregants also confirmed that they conformed to the government and WHO directives as communicated to them by their church leaders. One congregant says in an online survey dated 01/06/2020 that, 'we are staying indoors, using masks, keeping proper social distancing and getting tested'. Some church congregates, however, expressed mixed reactions. They revealed that some of their church members were 
not taking the government and WHO directives and guidelines seriously and 'they are not washing and sanitising their hands, observing social distancing and wearing masks'.

\subsection{Impact of the Covid-19 Pandemic on the Church Members and Activities}

In an endeavour to assess the role that the leadership of AFMZ were playing in response to COVID-19, the researcher also asked the respondents to online survey questions on the ways that the pandemic affected their respective assemblies financially and they all indicated that their financial positions were hard hit. One respondent had this to say:

$90 \%$ of my congregants are informal traders and due to the national lockdown, they are failing to conduct their usual businesses. Consequently, there is now fewer money which is coming to church as offerings or tithes (Online survey dated 02/06/2020).

One respondent had this to say:

The church's finances are usually supported by tithes and offerings which are hard to come due to non-gathering. Tithes are also heavily affected due to the fact that most congregants are in the informal traders' sector which hasn't been operating since the beginning of lockdown hence the congregants are even finding it difficult to get money to give to the church in order to support the work of God (Online survey dated 02/06/2020).

Some members also confirmed that due to lockdowns necessitated by the COVID-19 pandemic, they are even failing to pay offerings to the church and even tithes and that has resulted in the depletion of their assembly's finances, some are even failing to look after their leaders' welfare. Among other important traditional gatherings, the church cancelled the Young People's Union and Ladies conferences which were scheduled for April.

When the researcher asked AFMZ church leadership on the methods they have put in place to ensure that they recover from some of the losses some of them highlighted that, 'in-order to reduce the losses, we have reduced some of our expenses such as fuel and airtime allowances and we have also ventured into selling of face masks and sanitisers'. Others revealed that they are encouraging their church members and especially those who are formally employed to be faithful in paying their tithes and offerings through online mobile platforms such as Ecocash.

Apart from financial implications, responses elicited from the online survey revealed that unity among church members has been compromised by COVID-19 pandemic. The church and its leadership are failing to communion with their congregants and even to comfort or console the bereaved. One respondent says that due to financial constraints they are failing to buy airtime or data bundles to make a call or to send short message services or to communicate with their congregates via social media platforms like WhatsApp and Facebook. Thus, due to COVID-19 they are failing to bring new converts or to nurture new converts. Most of the church members have backslide. The general spirituality of the assembly has been affected since members cannot all participate in online sermons. 


\subsection{Limitations to Responses to the Pandemic by the AFMZ}

AFMZ Church leadership also highlighted that they are failing to buy sanitisers and to reach to their congregation especially in the rural areas where access to network is very poor and other members do not even have the gadgets that allow them to be reached out apart from the usual physical gatherings or meetings. Other respondents highlighted that due to diminished finances they are failing to by Protective Personal Equipment (PPE) such as facemasks, gloves and sanitisers or soaps to give to the less privileged in society.

The researcher also asked the Leadership of AFMZ on some of the constraints and strengths to their efforts to respond to COVID-19 and the general consensus was that due to major financial support they are failing to provide spiritual and theological resources like prayers, bible studies, reflections; supporting community preparedness, supporting people living in lockdown: including caring for children, home schooling, coping with stress and family pressures, tackling domestic violence, sustaining hope and care for the most vulnerable and building a more connected, resilient and compassionate society for the future.

In terms of initiatives the leadership have embarked upon to augment efforts by the government and other players in support of the COVID -19 response 95\% of them indicated that they were conscientizing people about the reality and dangers of the pandemic through audio sermons they are sending via online social media platforms since some of them are in denial about the dangers of the pandemic. They also said that through these audio sermons they are dispelling fears and falsehoods in Christians and non-Christians and replacing them with messages of hope and messages which increases their faith in the midst storms such as COVID-19. One remarkable response was that, 'we are helping in dispelling fear by quoting scriptures such as Mathew 8:23-27 which reads as follows:

And when he was entered into a ship, his disciples followed him.

And, behold, there arose a great tempest in the sea, insomuch that the ship was covered with the waves: but he was asleep.

And his disciples came to him, and awoke him, saying, Lord, save us: we perish.

And he saith unto them, Why are ye fearful, O ye of little faith? Then he arose, and rebuked the winds and the sea; and there was a great calm.

But the men marvelled, saying, What manner of man is this, that even the winds and the sea obey him! (Mathew 8:23-27)

Some of the AFMZ leadership also indicated that they are using scriptures such as Leviticus 13:1-46 which underscores the need for social distancing and isolation so as to instil in the congregates and the community at large to respect and put in the practice the precautionary measures put in place by the government of Zimbabwe. They said that there is also biblical mandate to isolate oneself (social distancing) for the benefit of others as described in Leviticus. Thus, communicable disease outbreaks may require that people distance 
themselves from one another. During COVID-19 people seriously need to consider gathering in a specified location, that is, church, day-care or school.

Some church leaders also indicated that they are also offering food and free counselling to those in need. One respondent said that, 'Although limited finances is obviously a hindrance to the efforts as well as the failure of the government to recognise the church and church leadership as an essential service and service providers respectively, we have however under these restrictions managed to give counselling and food assistance to those in need' (Online survey dated 02/06/2020). Another interesting response which is worth quoting came from a respondent from Midlands province who that, 'The only fight we had was to comply with the government not to congregate at our places of worship. What else could we do since we were on lockdown and received no financial support from the government to educate the masses' (Online survey dated 02/06/2020).

\section{Discussion of Findings}

Although there seem to be some differences in what COVID-19 is and how it is transmitted amongst the leadership, $95 \%$ of the respondents however shared a similar understanding of what it is and because of that they all managed to have a common message they relayed to their congregants on how to prevent themselves from contracting and infecting others with the virus such as practicing good hygiene and social distancing amongst other things. Nevertheless, 5\% of the respondents believed that COVID-19 is something unnatural and from the devil. In other words, they likened it to an evil spirit and evil spirits by their nature calls for a spiritual warfare. Spiritual warfare requires spiritual weapons. In this regard, the fight against COVID-19 requires prayers and it is through prayer and fasting that one will get protection from contracting or getting infected. Put differently, those who viewed coronavirus as a spiritual ailment ended up seeking treatment or solutions through prayer alone. Online sermons on divine healing became the order of the day. Community members who viewed coronavirus as spiritual were therefore slow to understand both the distortions of the messages and the ways in which common traditional practises, such as the laying of hands, contributed to the spread of the pandemic.

These respondents therefore did not see the precautionary measures or directives by the government and WHO as the most effective ways of preventing one's self from contracting COVID-19 apart from prayers and the gospel of faith. Thus, the church leadership contributed by relaying more messages or sermons that focused more on the spiritual aspect of the pandemic and they put less emphasis on the precaution measures as directed by WHO. The above position was evident on some of the congregants who did not bother to wear facemasks, observe social distance amongst other things since they believed that God will always protect them and no disease or sickness will catch them if God did not permit. They pointed that they live by grace. No mask or washing of hands will protect them if God does not permit. Thus, it is time that kills and not coronavirus. These divergent views on what coronavirus is and how it can be prevented led to different approaches or gospels or behaviours amongst the leadership and congregants of one church.

Although there seem to be different understandings of what COVID-19 is, the church 
leadership played and is still playing significant roles in changing the attitudes of the congregates towards the pandemic. Stone (2002) posits that churches should care and sacrifice for the community and in light of that, AFMZ leadership through their online audio sermons are playing vital roles towards the fight against COVID-19 both at the spiritual and physical levels. The sermons are helping congregants and the nation at large, firstly, spiritually by communicating to them messages of faith and hope and dispelling fears of the pandemic in them. Secondly, these online sermons are aiding physically by teaching the congregants and the nation at large the importance of following laid down precautionary measures to avoid contracting the virus or preventing the further spreading of the pandemic. These precautionary measures include washing of hands with soap and running or flowing water, sanitising hands and surfaces, practising coughing etiquette all the time and observing the lockdown guidelines like staying at home when not feeling well, they are managing to do this by using biblical references such as Leviticus the midst of storms.

While practical theology says that the church apart from providing prayers and the living sermons to the nation to feed the inner spirit they are also expected to look after the physical needs of the nation. Although their finances were limited, AFMZ leadership managed to provide some few foodstuffs to the less privileged people in their respective communities and also to the government of Zimbabwe and over 30 tonnes of food humpers to the Ministry of Social Welfare in response to COVID-19 they are however failing to do more due to limited finances.

The responses from the survey revealed that COVID-19 came with it with various challenges especially to people who are informally employed due to the lockdown which was put in place by the Zimbabwean government end of March 2020 in order to curb the further spread of the pandemic. These lockdowns affected the church congregants and the nation at large in a big way financially. These people have been finding it difficult to put food on their tables and worse still to spare some money to give to the church as love offerings and tithes, it is through these love offerings and tithes that the finances of AFMZ are mostly sustained from.

Thus, the few donations that they managed to do were coming from the church coffers, be it at national or assembly levels. Consequently, the very few people who managed to pay their love offerings and tithes could not raise enough money to meet all the financial obligations of the church, let alone the welfare of their leadership. In trying to keep their financial expenses down, most church leadership revealed that some have reduced their travel expenses by reducing the quantities of fuel they use in carrying out their church business. Others are even finding it difficult to raise money from their respective assemblies needed to buy airtime or data bundles in order to keep in touch with their congregants especially in these trying times. In view of the above, the church leadership is therefore failing to meet both their spiritual and physical obligations to their church congregants and the nation at large as underscored by Stone (2002) when she says that churches should care and sacrifice for the community.

The research findings, thus, indicated that due financial constraints, the leadership of AFMZ failed to reach out to more people in quarantine with prayers or foodstuffs and personal protective equipment. They could not afford to buy airtime to call those in quarantine or even 
to contact especially the older members of their church, who are/were considered to be more at risk of getting infected with the coronavirus than the younger people due to weakened immune systems, in order to strengthen their souls. They could not afford to provide healthcare services to the less privileged or those infected and affected by the pandemic. Lastly, the responses above also indicated that AFMZ church leadership played a very important role in response to COVID-19 through their counselling services.

\section{Recommendations}

In view of the above findings, the paper recommends that more finance should be availed to church leadership especially from the main church coffers to enable them to meet the above-mentioned demands in times of pandemics where financial coffers of the church's various assemblies may be very low due to limited income from church members in the form of offerings and tithes. Apart from relying from love offerings and tithes, the paper or recommends that the church should look for donations in cash and kind outside their church in order to be able to look after their neighbours in times of storms such as coronavirus pandemic.

Through financial donations the church may also be able to set its own healthcare centres and religiously run clinics and hospitals that will complement those in the public sector in the midst of difficult times.

In an attempt to avoid different understandings of the same pandemic, the paper recommends that AFMZ should put in place the church leadership COVID-19 taskforce focussed on framing and disseminating media messages on prevention and how to respond when cases are reported (Featherstone, 2015). Communication is key in times of pandemic and it is therefore vital for the church to have one clear position on what COVID-19 is in order to allow itself to build trust among communities and conveying clear messages about the causes of the pandemic, which is significant to bringing the epidemic under control.

What is more, the government need to be reminded on the important role that faith leadership in any country play especially during crises. Community buy in is very important in times of pandemics. Marshall (2014) avers that:

The high levels of distrust toward the governments emerged as a critical problem as communities ignored official messages.... [and] .... Religious leaders were more exempt from these taints than others and many were trusted community leaders, looked to provide guidance on many aspects of life, spiritual and beyond

The excerpt above shows that trusted faith religious actors can play important roles in pandemic situations. The government of Zimbabwe should come to appreciate that religious institutions and beliefs are essential players in the fight against pandemics such as coronavirus, because they are trusted and because their dense community networks offer a useful way to gain knowledge and to communicate. It is therefore recommended that the government should partner with faith leadership or institutions and also provide them with financial support in order to have enhanced response to COVID-19. 


\section{Conclusion}

The paper sought to unravel the role that AFMZ leadership is playing in the fight against COVID-19 particularly in relation to social mobilisation, physical assistance, stigmatisation and psychosocial support and it was found out that the church is focusing more on the spiritual side of the pandemic. They are offering prayers and psychosocial support to a smaller extent though. Due to financial constraints, the paper revealed that they are not doing much in terms of physical assistance to those infected and affected by coronavirus disease such as PPEs and foodstuffs, to mention, but a few.

\section{References}

Ammerman, N. T. (2001). Doing good in American communities: Congregations and service organizations working together.

Cnaan, R. A., \& Boddie, S. C. (2001). Philadelphia census of congregations and their involvement in social service delivery. Social Service Review, 75(4), 559-580.

Donnelly, N., \& McManus, J. (2006). Pandemic Flu: The Role of the Church. The Furrow, 57(12), 657-663.

Featherstone, A. (2015). Keeping the faith: The role of faith leaders in the ebola response. CAFOD, London, UK. Https://Reliefweb. Int/Report/Sierra-Leone/Keeping-Faith-Role-Faith-Leaders-Ebola-Response.

Feldman, D. A. (1995). High-risk sexual behavior among some female Zambian out-of-school adolescents: a possible future application of the value utilization/norm change model. Society for Applied Anthropology Meeting, Albuquerque.

French, M., Fiztgibbon, A., Ager, W., Ager, A., \& Horn, R. (2018). A Faith-Sensitive Approach in Humanitarian Response. Islamic Relief Worldwide.

Hodge, D. (2000). The spiritually committed: An examination of the staff at faith-based substance abuse providers. Social Work and Christianity, 27(2), 150-167.

Kaulemu, D. (2010). Church responses to the crisis in Zimbabwe. The Review of Faith \& International Affairs, 8(1), 47-54.

London, C. M. (1998). Dunant s Dream: War, Switzerland and the History of the Red Cross.

Luther, M. (1527). Whether One May Flee from a Deadly Plague'[1527]. Luther's Works, Ed. J. Pelikan and HT Lehmann (56 Vols, Philadelphia, 1968), 43, 119-138.

Marshall, K. (2014). Ebola: Ten Proposals to Engage Religious Actors More Proactively. The Huffington Post, October, 8.

Mukuka, L., \& Slonim-Nevo, V. (2006). The role of the church in the fight against HIV/AIDS infection in Zambia. International Social Work, 49(5), 641-649.

O'Mathuna, D. (1995). The Bible and abortion: What of the 'image of God.' Bioethics and the Future of Medicine, 199-211. 


\section{Macrothink}

Journal of Public Administration and Governance ISSN 2161-7104 2020, Vol. 10, No. 3

Orubuloye, I. O., Caldwell, J. C., \& Caldwell, P. (1993). The role of religious leaders in changing sexual behaviour in southwest Nigeria in an era of AIDS. Health Transition Review, 93-104.

Slonim-Nevo, V., \& Mukuka, L. (2005). AIDS-related knowledge, attitudes and behavior among adolescents in Zambia. AIDS and Behavior, 9(2), 223-231.

Sobrino, J. (2015). Where is God?: earthquake, terrorism, barbarity, and hope. Orbis Books.

Stark, R. (1996). The rise of Christianity: A sociologist reconsiders history. Princeton University Press.

Stone, D. (2002). Policy paradox: the art of political decision-making, New York: W. W. Norton \& Company.

Togarasei, L. (2016). Historicising Penteoostal Christianity in Zimbabwe. Studia Historiae Ecclesiasticae, 42(1), 1-13.

\section{Copyright Disclaimer}

Copyright for this article is retained by the author(s), with first publication rights granted to the journal.

This is an open-access article distributed under the terms and conditions of the Creative Commons Attribution license (http://creativecommons.org/licenses/by/4.0/). 